\title{
IAMJ
}

INTERNATIONAL

AYURVEDIC

MEDICAL JOURNAL

ISSN: 2320-5091

Impact Factor: 6.719

\section{UNDERSTANDING OF PATHOPHYSIOLOGY OF KUSHTA WITH SPECIAL REFERENCE TO PSORIASIS}

\section{$\underline{\text { Pavitra }}^{1^{*}}, \underline{\text { Farida Begum Shaik }}^{2}, \underline{\text { Madhava Diggavi }}^{3}$}

${ }^{1}$ PG Scholar, ${ }^{2}$ Professor and Guide, ${ }^{3}$ Professor and HOD, Department of PG studies in Kayachikitsa, Taranath Government Ayurvedic Medical College and Hospital, Ballari, Karnataka, India

Corresponding Author: pavithrategampur@gmail.com

\section{https://doi.org/10.46607/iamj1309042021}

(Published online: April 2021)

Open Access

(C) International Ayurvedic Medical Journal, India 2021

Article Received: 17/03/2021 - Peer Reviewed: 19/03/2021 - Accepted for Publication: 20/03/2021

\section{Check for updates}

\section{ABSTRACT}

The main objective of this review is to understand of pathophysiology of Kushta with special reference to psoriasis. Sapta Dravya that is Tridosha, Twak, Raktha, Mamsa and Lasika plays an important role in pathogenesis of Kustha. Psoriasis is a chronic inflammatory, hyper proliferative, erythematous scaly plaques skin disease. Langerhans cells and other factors plays in pathology of psoriasis. In this article we tried to explain pathology of Kustha with special reference to psoriasis.

Keywords: Kushta, Psoriasis

\section{INTRODUCTION}

"Kushnati Vapu: Iti Kushta"1 or "Kustham Shareeram Kushnati Kutchitam Karoti" "2 means that which makes once skin look disgraceful or ugly or which destroys Twak and other Dhatus is called Kustha. Caused by vitiation of Tridosha, that vitiates the Rasa or Twak,
Raktha, Mamsa and Lasika. Psoriasis is a chronic inflammatory, hyper proliferative skin disease. It is characterized by well defined, erythematous scaly plaques. Affecting around $20 \%$ of the population, can arise at any age of 20-60 years and for both genders ${ }^{3}$. 
Psoriasis occurs when immune system overreacts causing prolonged inflammation of skin as in Kushta. Pathogenesis of psoriasis is debatable. However, one accepted fact is that the time necessary for a psoriatic epidermal cell to travel from basal cell layer to the surface and be cast of is 3 to 4 days, in contrast to the normal 26 to 28 days. The mechanism underlying this rapidly increased epidermal transit time is still speculated $^{4}$.

\section{Applied Aspects of Skin:}

Skin is a complex organ that protects its host from its environment, at the same time allowing interaction with its environment. It is much more than a static, impenetrable shield against external insults. Skin provides physical permeability barrier, protection, thermoregulation, sensation, UV protection, wound repair and regeneration and outward physical appearance. These various functions of skin are mediated by one or more of its major regions- the epidermis, dermis and hypodermis. The epidermis and its outer stratum corneum provide a large part of the physical barrier provided by skin, the structural integrity of skin as a whole is provided primarily by the dermis and hypodermis. Antimicrobial activities re provided by the innate immunity system and antigen-presenting dendritic cells of the epidermis, circulating immune cells that migrate from the dermis, and antigen-presenting cells of the dermis. Protection from UV irradiation is provided in great measure by the most superficial cells of the epidermis. Inflammation begins with the keratinocytes of the epidermis or immune cells of the dermis, and sensory apparatus emanates from nerves that initially traverse the hypodermis to the dermis and epidermis, ending in specialized receptive organs or free nerve endings. The largest blood vessels found in the hypodermis, which serve to transport nutrients and immigrant cells. The cutaneous lymphatics course through the dermis and hypodermis, serving to filter debris and regulate tissue hydration ${ }^{5}$.

\section{Pathology of Kushta}

The Doshas irrespective Hetus get vitiated and spread throughout the body which inturn vitiates Dhatus and manifests disease ${ }^{6}$. Sapta Dravyas called Sapta Dushya Sangraha, when disturbed lead to the genesis of Kushtha ${ }^{7}$. They are three Doshas -Vata, Pitta and Kapha and four Dushyas -Tvak, Mamsa, Rakta and Lasika (Ambu). Then Kushtha spreads to the entire body by its Prabhava, the dual part played by Nidana that is simultaneous vitiation of Tridosha and also Shaithilyata in the Dhatus such as Twak, Rakta, Mamsa and Lasika. Thus, vitiated Tridoshas gains momentum to vitiate Shithila Dhatus and hence the disease Kushtha gets manifested $4^{8}$.

Acharya Sushruta described that due to Doshaja and Karmaja Hetus, aggravation of Pitta and Kapha takes place which produce Avarana of Vata which inturn aggravates Vata. Vitiated Vata enters in the Tiryaka Sira with two others vitiated Doshas and their spread leads to further vitiation. After this it reaches to Bahya Rogamarga (Tvak, Rakta, Mamsa, Lasika) and spread throughout the body, producing Mandala at the gathering site of Doshas. If these Doshas are not treated properly. After that they enter into the deeper Dhatus of the body ${ }^{9}$.

Nidana Sevana, Doshaja and Karmaja Hethu $\longrightarrow$ Tridosha Prakopa by avarana of vata $\longrightarrow$ Twak, Rakta, Mamsa and Ambu Shaithilyata $\longrightarrow$ Vitiated Vata enters in the Tiryak Sira and Further Vitiation of Doshas

$\longrightarrow$ Doshas gets accumulated at the place of Dhatu Shaithilyata, Bahya Rogamarga $\longrightarrow$ Dosha and Dushya Samurchhana $\longrightarrow$ Kustha

\section{Cells and Humors of Psoriasis:}

Langerhans cells are dendritic and derived from bone marrow that circulate between the epidermis and local lymph nodes. Myeloid dendritic cells serve as a bridge linking adaptive and innate immune response, Naïve T-cells are responded to novel pathogens that the im- mune system has not yet encountered, TNF- $\alpha$ is an inflammatory cytokine produced by macrophages monocytes during acute inflammation. Is responsible for diverse range of signaling events within cells leading to apoptosis or necrosis, hyperproliferation of keratinocytes, vascular changes, inflammation and 
tissue damage. T-cell produces the cytokines and regulating the immune response. T- lymphocytes secrets the cytokines and direct killing of target cells. Th-1 cells regulate macrophages and monocytes. Th- 2 regulate eosinophils, basophils and mast cells. IL-12, IL23, IL-26, IL-27 and IL-28 are family of cytokines with pro-inflammatory properties.

\section{Pathology of Psoriasis}

The epidermis is infiltrated by a large number of activated $\mathrm{T}$ cells, which are capable of inducing keratinocyte proliferation. This is supported by histologic examination and immunohistochemical staining of psoriatic plaques revealing large populations of $\mathrm{T}$ cells within the psoriatic lesions ${ }^{10}$.

Ramped-up, deregulated inflammatory process ensues with a large production of various cytokines (e.g., tumor necrosis factor- $\alpha$ [TNF- $\alpha]$, interferon-gamma, interleukin-12), the clinical features of psoriasis are due to large production of such mediators. Interestingly, elevated levels of TNF- $\alpha$ specifically are found to correlate with flares of psoriasis Key findings in the affected skin of patients with psoriasis include vascular engorgement due to superficial blood vessel dilation and altered epidermal cell cycle. Epidermal hyperplasia leads to an accelerated cell turnover rate (from $28 \mathrm{~d}$ to 3-5 d), leading to improper cell maturation. Cells that normally lose their nuclei in the stratum granulosum retain their nuclei; a condition known as parakeratosis. In addition to parakeratosis, affected epidermal cells fail to release adequate levels of lipids, which normally cement adhesions of corneocytes. Subsequently, poorly adherent stratum corneum is formed leading to the flaking, scaly presentation of psoriasis lesions, the surface of which often resembles silver scales ${ }^{11}$.

Due to etiological factors $\longrightarrow$ Hyperactivity of T-cells $\rightarrow$ Epidermis infiltration and keratinocytes proliferation Deregulated inflammatory response $\rightarrow$ Large production of various cytokines (hormones) $\rightarrow$ Superficial blood vessels dilated and vascular engorgement $\rightarrow$ Epidermal hyperplasia and improper cell maturation

$\rightarrow$ Fails to release adequate lipid which leads to flacking, scaling presentation of psoriasis lesion $\rightarrow$ Silvery scale of the skin -psoriasis.

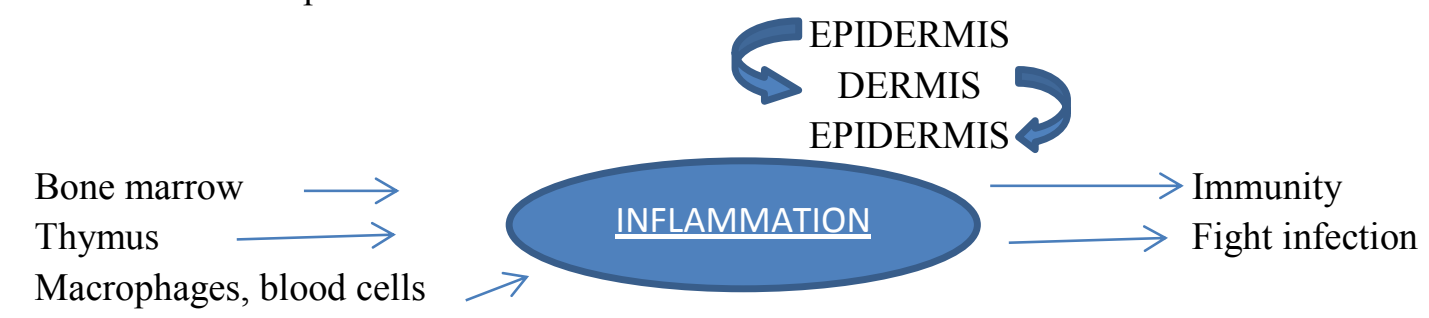

\section{Mechanism of psoriasis development:}

Etiological factors damage the keratinocytes, there is production of auto-immune anti-microbial peptides. Immature Langerhans cells recognize the auto antigen and normal antigen, after antigen recognition it might trigger the activation of myeloid dendritic cells. immature Langerhans cells starts maturing and reaches the lymph nodes (Rasa) after reaching lymph nodes they trigger activation of naïve T-cell. Activated naïve T-cell produces IL-12 other factors like TNF- $\alpha$, TNF$\gamma$ cause clonal proliferation of Th-1 type of cell (Vata) there activated $\mathrm{T}$ - lymphocytes possess an antigen called CLA and permits entry through dermal endo- thelial by interaction with ICAMs, finally activated Tcells reach into the dermis. The myeloid dendritic cells after activation produces TNF- $\alpha$ and IL-12, IL23. IL-23 activates immature Th-17 cells to mature Th-17 cells, IL-17 further activates its type of T-cells which are Th-17 T-cells, Th-17 T-cells produces IL17, IL-22,IL-26,29 and TNF- $\alpha$. Il-12 causes activation of chemotaxis (Amavisha) of Th-1 cells, there activated Th- 1 cells further produces IFN- $\gamma$ and TNF$\alpha$ and these further activates Th-1 type of immune cells. The lymphocytes which enter into the skin also trigger IL-17 and IL-22 production. All these interleukin release cause epidermal and dermal changes, vas- 
cular proliferation and epidermal proliferation and synthesis of chemokines. Chemokines further attract the lymphocytes into the skin peculiarly IL-18 causes attraction of neutrophils into the lesion. All these chemokines further cause triggering and activation of MDCs, plasmocytoid dendritic cells get trigger first and produce IFN- $\alpha$ and $\beta$ which further activates myeloid dendritic cells and same process continued.

\section{DISCUSSION}

Regarding pathogenesis, the epidermis is infiltrated by a large number of activated $\mathrm{T}$ cells, which appear to be capable of inducing keratinocyte proliferation. Key findings in the affected skin include vascular engorgement due to superficial blood vessel dilation and altered epidermal cell cycle. Epidermal hyperplasia leads to an accelerated cell turnover rate (from $23 \mathrm{~d}$ to 3-5 d), leading to improper cell maturation. In addition to parakeratosis, affected epidermal cells fail to release adequate levels of lipids, which normally cement adhesions of corneocytes, as a result poorly adhered stratum corneum leads to flakes and scales of psoriasis. Samprapti of Kustha says as vitiated Tridoshas cause Saithilya Of Twak (skin or Rasa), Rakta (blood), Mamsa (muscle) and Lasika (lymph) take shelter there resulting in Kustha.

Kapha disturbance leads to immunological variations which favours the development of psoriasis. Due to Pitta disturbance there is a development of hyper proliferation of the keratinocytes in the epidermis. An increase in the epidermal cell turnover rate is because of vitiated Vata. Langerhans cells and myeloid dendritic cells are derived from bone marrow (Majja Dhatu), TNF- a (Raktha Dhathu), lymph node (Lasika) which play major role in the pathogenesis of psoriasis.

\section{CONCLUSION}

Present review has mainly focused on pathology of Kushta and psoriasis. Langerhans cells and other cells are all play major role in pathogenesis of psoriasis. Accelerated epidermopoiesis is explained as the basic event, whereas in Ayurveda Vikritha Tridosha along with Twak, Raktha, Mamsa and Lasika which plays a main role in production of the Kushta. Hence Kushta will be treated by proper understanding of pathology of Kushta.

\section{REFERENCES}

1. Agnivesha, Charaka, Dridhabal. Charak Samhita, volume 2, Chaukambhabhaarti academy, Varanasi, 2005, $7 / 247$.

2. Indu, Astanga Samgraha, Nidan sthan, Kustha Nidanadhaya, 14/3, Sashilekha tika, ed. By Dr. Shivaprasad Sharma, Choukhamba Sanskrit series office, 2016, $\mathrm{p}$ (296).

3. Clinical dermatology, virendra $\mathrm{N}$ sehagal, fourth edition, Jaypee brothers' medical publishers, new delhi2004,126

4. Clinical dermatology, virendra $\mathrm{N}$ sehagal, fourth edition, Jaypee brothers' medical publishers, new delhi2004,126

5. fitzpatrick's dermatology in general medicine, edited by Lowell a et al, volume one, eighth edition,Mc Graw Hill company,2008, 58-59, 64.

6. Agnivesha, Charaka, Dridhabal. Charak Samhita, volume1, Chaukambhabhaarti academy, Varanasi, 2005, 607.

7. Agnivesha, Charaka, Dridhabal. Charak Samhita, volume 2, Chaukambhabhaarti academy, Varanasi, 2005, 248.

8. Byadgi P S. Kushtha. Parameswarappa's Ayurvediya Vikriti Vigyanand RogaVigyan, 1st edition, Volume II. Varanasi, Chaukhambha Sanskrit Sansthan, 2009; 26898

9. Sushurata. Sushruta Samhita, 14th edition, volume1, Chaukhambha Sanskrit sansthan, Varanasi, 2003,246.

10. Krueger JG, Bowcock A. Psoriasispathophysiology: Current Concepts of pathogenesis, Ann Rheum Dis.2005 Mar. 64 supp1.2: ii30-6[Medicine]

11. emedicine.medscape.com/article/1943419-overview

\section{Source of Support: Nil \\ Conflict of Interest: None Declared}

How to cite this URL: Pavitra et al: Understanding Of Pathophysiology Of Kushta With Special Reference To Psoriasis. International Ayurvedic Medical Journal \{online\} 2021 \{cited April, 2021\} Available from: http://www.iamj.in/posts/images/upload/773_776.pdf 